\title{
Deskripsi Tentang Pemanfaatan Sumber Mata Air Jompi Kelurahan Laende Kecamatan Katobu Kabupaten Muna
}

\author{
Vebrianti $^{1}$, La Ode Amaluddin ${ }^{2}$, Rahma Musyawarah $^{3}$ \\ 123 PROGRAM STUDI GEOGRAFI / UNIVERSITAS HALU OLEO \\ Email : ebisalsaf146@gmail.com
}

(Received: Agustus 2019; Reviewed: Agustus 2019; Accepted: September 2019; Published: Oktober 2019)

Ini adalah artikel dengan akses terbuka dibawah license CC BY-SA (C2019 oleh penulis (https://creativecommons.org/licenses/by-sa/4.0).

\begin{abstract}
Raha City is located on the coast of the Buton Strait, the capital of Muna Regency, Southeast Sulawesi Province. The total area of this city is $47.11 \mathrm{~km} 2$ consisting of 12 villages and 7 villages. Laende Urban Village Katobu Sub-District is a Sub-District which mostly utilizes Jompi spring to fulfill their daily needs. The purpose of this study was (1) to determine the environmental condition of the Jompi spring Laende Village Katobu District Muna Regency, (2) to describe the utilization of the Jompi spring Laende Village Katobu District Muna Regency. This research method uses qualitative descriptive research methods. Data collection techniques used were interviews and documentation study. The results of the research show that (1) the Jompi Spring Area which functions as a water catchment protected area and around the spring, physical and environmental conditions have experienced a decline with a lot of garbage, a decrease in water discharge based on data from the Duna Irrigation District of Muna, debit from the spring Jompi in 2010 amounted to \pm 25 liters / second. In this case it means that the debit has decreased ten times since the previous decade by \pm 50 liters $/$ second, and experienced sedimentation in spring one, which was caused by flooding submissions from rivers in Labaha Village (2) Sources of Jompi spring most of it is used to meet the clean water needs of the people of Raha City that are accommodated by the PDAM and then distributed to the homes of residents not only that the source of water is also used for berendan and recreation. As for the remote areas in the city of water in the sub-education through pickup cars that are paid 25 thousand
\end{abstract}

Keywords: Utilization, Jompi Springs, Muna Regency

\section{ABSTRAK}

Kota Raha terletak di pesisir Selat Buton, merupakan ibu kota Kabupaten Muna, Provinsi Sulawesi Tenggara. Total area dari kota ini adalah 47,11 km2 terdiri dari 12 kelurahan, dan 7 desa. Kelurahan Laende Kecamatan Katobu merupakan Kecamatan yang sebagian besar memanfaatkan mata air Jompi untuk memenuhi kebutuhan hidupnya. Tujuan dari penelitian ini adalah: (1) untuk mengetahui keadaan lingkungan sumber mata air Jompi Kelurahan Laende Kecamatan Katobu Kabupaten Muna: (2) untuk mendeskripsikan pemanfaatan sumber mata air Jompi Kelurahan Laende Kecamatan Katobu Kabupaten Muna.Penelitian ini merupakan penelitian deskripsi kualitatif. Teknik pengumpulan data yang digunakan adalah wawancara dan studi dokumentasi. Hasil peneltian menunjukan bahwa: (1) Kawasan Mata Air Jompi yang difungsikan sebagai kawasan lindung resapan air, kondisi fisik dan lingkungan sudah mengalami penurunan terlihat dengan banyak sampah, penurunan debit air berdasarkan data dari DPU Pengairan Kabupaten Muna, debit 


\begin{abstract}
dari mata air Jompi pada tahun 2010 sebesar \pm 25 liter/detik. Dalam hal ini berarti telah mengalami penurunan debit sebesar sepuluh kali sejak dekade terakhir yang sebelumnya sebesar \pm 50 liter/detik, dan mengalami sedimentasi di mata air satu yang di akibatkan oleh banjir kiriman dari sungai yang ada di Desa Labaha: (2) Sumber mata air Jompi sebagian besar di manfaatkan untuk memenuhi kebutuhan air bersih masyarakat Kota Raha yang di tampung oleh PDAM lalu di salurkan ke rumah rumah warga bukan hanya itu sumber mata air juga dimanfaatkan untuk berendan dan rekreasi. Adapaun untuk daerah daerah terpencil yang ada di kota raha air di distribusikan melalui mobil-mobil pik-up yang di bayar sebesar 25 ribu.
\end{abstract}

Kata Kunci: Pemanfaatan, Mata Air Jompi, Kabupaten Muna

\title{
PENDAHULUAN
}

Mata air merupakan pemunculan air tanah ke permukaan tanah. Pemanfaatan mata air sangat beragam, antara lain penggunaan untuk keperluan air minum, irigasi, perikanan, dan obyek wisata. Lebih lanjutnya dijelaskan bahwa

mata air adalah tempat dimana air tanah merembes atau mengalir keluar permukaan tanah secara alamiah. Mata air adalah tempat pemunculan air tanah pada lapisan akuifer dari bawah permukaan tanah ke atas permukaan tanah secara alamiah. Selanjutnya, air yang keluar dari mata air akan mengalir di permukaan tanah sebagai air permukaan melalui alur-alur sungai. Mata air sering diidentifikasikan sebagai awal sumber air bagi sungai-sungai yang ada (Hendrayana, (2013).

Air merupakan salah satu sumber daya alam yang memiliki fungsi sangat penting bagi perikehidupan manusia, serta untuk memajukan kesejahteraan umum, sehingga air merupakan modal dasar dan faktor utama pembangunan. Kebutuhan manusia akan air sangat kompleks, antara lain untuk minum, masak, mandi, mencuci, dan sebagainya (Tunggul, 2012).

Salah satu potensi sumber daya alam yang dapat mendukung pembangunan adalah sumber daya air. Air merupakan sumber daya alam karunia Allah SWT yang sangat diperlukan oleh manusia sepanjang masa dan menjadi bagian dari kebutuhan dasar manusiawi yang sangat penting (Kodoatie, 2011). Air juga sangat diperlukan dalam pembangunan hampir di semua sektor, dari sektor pertanian dan perikanan, sarana dan prasarana, lingkungan sampai dengan pariwisata. Air di gunakan untuk air minum, air untuk irigasi, air untuk kebutuhan sehari-hari seperti mandi dan mencuci, air untuk kebutuhan industri maupun air yang digunakan untuk keperluan lain seperti pemancingan dan kolam renang. Keberlanjutan sumber daya air ini perlu dijaga manfaatnya yang sangat penting dalam kehidupan dan pembangunan (Waryono, 2010).

Potensi lain yang juga dapat di manfaatkan oleh daerah dalam pemnafaatan sumber mata air adalah potensi pariwisata. Pengembangan pariwisata ini ditunjukan untuk mengembangkan suatu wilayah atau daerah dalam rangka menambah nilai tambah dan meningkatkan kesejahteraan masyarakat suatu daerah. Tetapi efek dari pembungunan pariwisata di suatu daerah adalah timbulnya dampak baik itu positif maupun negatif. Dampak negatif umumnya terjadi pada komponen sosial budaya dan lingkungan fisik, sedangkan dampak positif terjadi pada komponen sosial ekonomi dan kedua dampak ini biasanya terjadi dalam rantai panjang (Fandeli, 2011).

Dampak atau pengaruh positif yang dapat timbul dari pariwisata adalah makin luasnya kesempatan usaha, makin luasnya lapangan kerja, meningkatnya pendapatan masyarakat dan pemerintah, mendorong pelestarian budaya dan peninggalan sejarah, mendorong terpeliharanya lingkungan hidup, terpeliharanya keamanan dan ketertiban, mendorong peningkatan dan pertumbuhan di bidang pembangunan sektor lainnya. Sedangkan dampak negatifnya adalah harga di daerah yang menjadi tujuan pariwisata makin tinggi, terjadi pencemaran lingkungan alam dan lingkungan hidup, terjadi sifat ikut-ikutan dari masyarakat setempat, timbulnya sikap mental materialistis, timbulnya sikap meniru wisatawan, meningkatnya tindakan pidana (Karyono, 2011).

Salah satu aset yang dimiliki oleh Kabupaten Muna adalah kawasan sumber mata air Jompi. Kawasan sumber mata air Jompi ini merupakan tempat atau wilayah yang terletak di Kelurahan Laende, Kecamatan Katobu. Dalam arahan RTRW Kabupaten Muna kawasan mata air Jompi ini 
difungsikan sebagai kawasan lindung yaitu sebagai kawasan perlindungan sekitar mata air dan kawasan perlindungan resapan air. Difungsikan demikian karena di kawasan sumber mata air Jompi ini terdapat beberapa sumber mata air yang mempunyai debit yang cukup besar sehingga mampu memasok kebutuhan air bagi daerah sekitarnya.

Kawasan mata air Jompi juga dimanfaatkan sebagai sumber air bersih oleh PDAM Kota Raha karena besarnya debit air yang keluar, untuk pemenuhan kebutuhan masyarakat terhadap kebutuhan air bersih yang berdomisili di ibu kota Kabupaten Muna. Sedangkan bagi masyarakat yang berdomisili di daerah pedesaan umumnya menggunkan air dari sumur, mata air, air hujan, atau membeli air bersih yang di jual.

Keunikan yang menonjol dari kawasan ini adalah kawasan ini dimanfaatkan masyarakat untuk rekreasi menikmati sumber mata air seperti berendam, mandi, dan lain sebagainya. Pemerintah Daerah Kabupaten Muna berencana untuk menata kembali kawasan sekitar mata air dan beberapa tempat permandiannya, sebagai salah satu obyek wisata air tawar, wisata alam dan budaya sesuai Rencana Induk Pengembangan Pariwisata Kabupaten Muna. Namun dalam perkembanganya kondisi lingkungan fisik kawasan mata air Jompi saat ini justru sudah mengalami penurunan. Hal ini terlihat dari banyaknya sampah yang ada akibat aktifitas pengunjung, penurunan debit air, serta berkurangnya vegetasi di areah mata air.

Mata air Jompi di Kelurahan Laende merupakan aliran air tanah yang muncul di gua bawah tanah dan liang yang terletak pada kawasan hutan lindung jompi sehingga pada lokasi tersebut di jumpai berbagai macam tumbuh-tumbuhan termasuk pohon jati, longkida, dan beringin. Mata air tersebut merupakan sumber utama yang di manfaatkan oleh masyarakat desa untuk memenuhi kebutuhan air sehari-hari khususnya pada saat musim kemarau tiba karena kondisinya yang terus mengalir sepanjang tahun dan tidak pernah mengalami kekeringan.

Berdasarkan uraian diatas, maka penulis tertarik untuk melakukan penelitian yang berjudul "Deskripsi Tentang Pemanfaatan Mata Air Jompi Kelurahan Laende Kecamatan Katobu".

\section{METODE}

Jenis penelitian adalah deskripstif kualitatif untuk memberikan gambaran atau deskripsi tentang pemanfaatan sumber mata air Jompi Kelurahan Laende Kecamatan Katobu Kabupaten Muna Penelitian ini akan dilaksanakan di Kelurahan Laende Kecamatan Katobu Kabupaten Muna Subjek penelitian ini adalah kantor Lurah Laende, ketua Rt dan warga masyarakat yang berasal dari Kelurahan Laende. Jumlah responden sebanyak 22. Terdiri dari 15 orang laki-laki dan 7 orang perempuan. Teknik pengumpulan data dalam penelitian ini adalah dengan mewawancarai pak Lurah di kantor kelurahan dan masyarakat serta melakukan dokumentasi atau pengambilan gambar untuk memperkuat hasil penelitian. Data dalam penelitian ini dianalisis dengan menggunakan analisis deskriptif kualitatif yang bertujuan untuk memberikan gambaran sejauh mana pemanfaatan dari mata air Jompi yang ada di Kelurahan Laende Kecamatan Katobu

\section{HASIL DAN PEMBAHASAN}

\section{Hasil}

\section{A. Keadaan Lingkungan Sumber Mata Air Jompi}

Kawasan hutan lindung Jompi memiliki luas \pm 1.927 ha atau 4,2 persen dari luas kawasaan hutan lindung di Kabupaten Muna. Dari luas Kawasan hutan lindung Jompi tersebut, \pm 1.233 ha atau 64 persen adalah hutan jati alam dan \pm 694 ha atau 36 persen adalah hutan campuran.

\section{Deskripsi Lokasi penelitian}

Kota Raha terletak di pesisir Selat Buton, merupakan ibu kota Kabupaten Muna, Provinsi Sulawesi Tenggara. Total area dari kota ini adalah 47,11 km2 terdiri dari 12 kelurahan, dan 7 desa, dengan jumlah penduduk 53.246 jiwa, dengan kepadatan 1130,24/km2 (BPS, 2015).

\section{Kawasan Lindung}

Sesuai konteksnya bahwa kawasan lindung adalah kawasan yang di tetapkan dengan fungsi utama melindungi kelestarian lingkungan hidup yang mencangkup sumber alam, sumber daya 
buatan dan nilai sejarah serta budaya bangsa guna kepentingan pembangunan berkelanjutan. Sedangkan yang dimaksud pembangunan berkelanjutan menurut World Commission on Environment and Development adalah pembangunan yang ditunjukan untuk memenuhi kebutuhan generasi yang akan datang untuk memenuhi kebutuhan mereka sendiri (Hadi, 2011). Disini ada dua aspek penting yaitu aspek kebutuhan dan aspek keterbatasan kemampuan lingkungan untuk memenuhi kebutuhan generasi sekarang dan generasi yang akan datang.

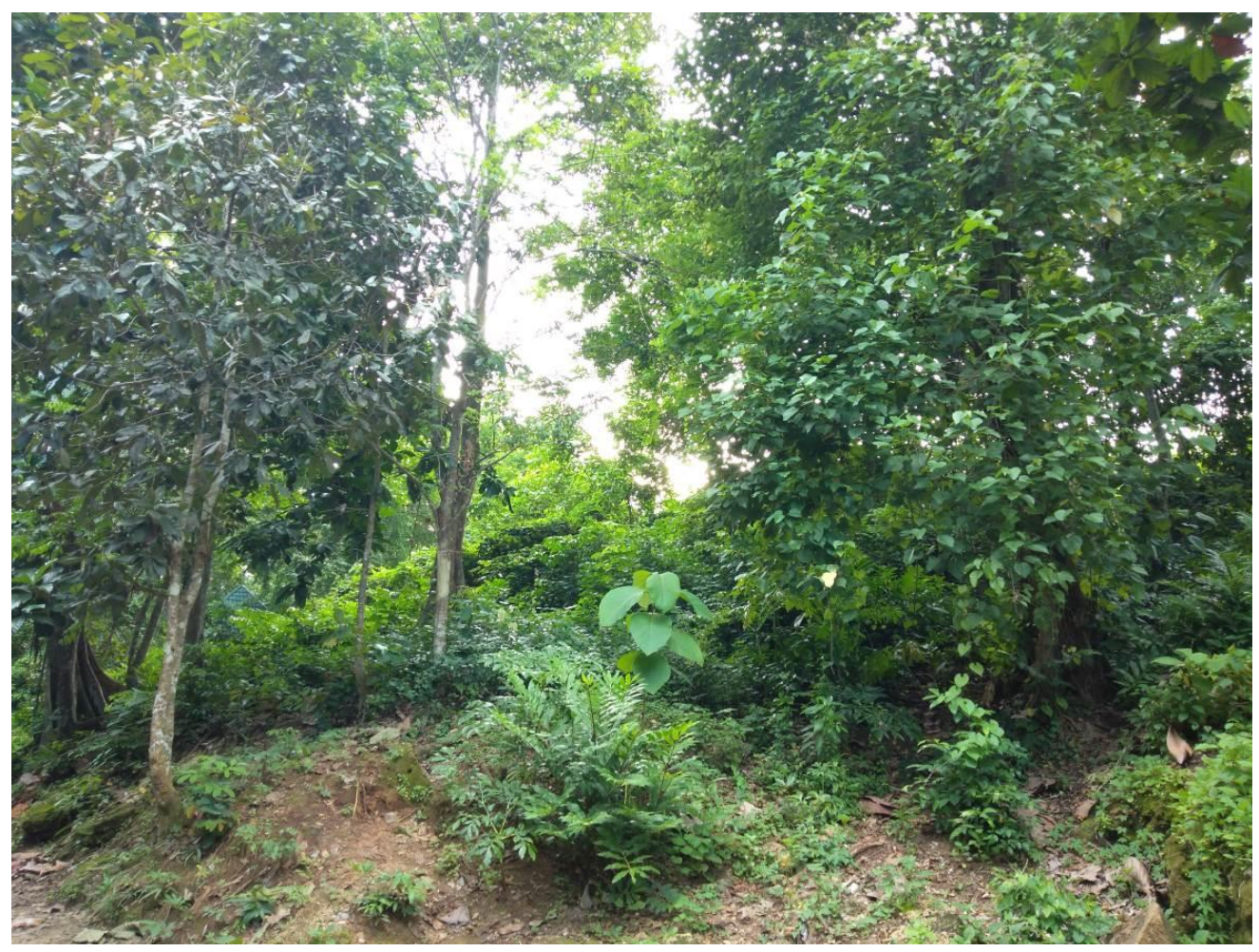

Gambar 1. Kawasan Hutan Lindung (Hasil observasi 2019)

Kegiatan-kegiatan yang berlangsung di kawasan Jompi harus memperhatikan kaidah-kaidah kawasan yang dilindungi. Hal ini disebabkan di Kawasan Jompi ini terdapat sumber mata air dengan debit yang cukup besar. Karena debitnya yang besar menjadikan air dari mata air Jompi menjadi sumber air bersih bagi PDAM Kabupaten Muna, Kota Raha.

Lahan-lahan disekitar sumber mata air ini masih berupa hutan ataupun tanah dengan pohonpohon besar yang berfungsi menahan dan meresap air pada waktu hujan. Sebagai kawasan lindung secara fisik lingkungan kawasan Jompi sudah mengalami penurunan. Selain sampah yang tidak terkelola dengan baik, mata air satu yang ada di kawasan Jompi juga sudah mengalami pendangkalan karena sedimentasi yang berasal dari sungai yang ada di Desa Labaha yang mengalami kebanjiran ketika hujan turun sehingga membawa material-material (pasir, tanah atau debu) sehingga terjadi pendangkalan pada area mata air satu. Selain itu rusaknya ekosistem hutan akibat dari ulah beberapa kelompok yang melakukan penebangan liar dan tidak bertanggung jawab atas perbuatannya. Penurunan kualitas lingkungan yang lain adalah debit air dari mata air Jompi walaupun masih tergolong besar tetapi sudah mengalami penuruna, Berdasarkan data dari DPU Pengairan Kabupaten Muna, debit dari mata air Jompi pada tahun 2010 sebesar \pm 25 liter/detik. Dalam hal ini berarti telah mengalami penurunan debit sebesar sepuluh kali sejak dekade terakhir ini. Sebelum terjadi penurunan debit air \pm 50 liter/detik. 


\section{Kawasan Resapan Air}

Adapun keadaan kawasan resapan air, antara lain:

a) Lokasi kawasan mata air jompi yang berada di tengah-tengah hutan lindung jompi merupakan keistimewaan kawasan ini karena sumber mata air jompi yang memiliki mata air yang begitu banyak

b) Di Kawasan Mata Air Jompi juga masih banyak pohon-pohon besar dan semak belukar yang mampu menahan air dalam jumlah besar apabila terjadi hujan. Untuk daerah resapan air yang lebih luas di Kabupaten Muna, pohon-pohon besar sebagai penahan air masih banyak sehingga kualitas maupun kuantitas air yang dihasilkan dari mata air Jompi masih relatif banyak dan bagus.

c) Curah hujan yang lumayan tinggi yang dengan kondisi tanah yang mudah meresapkan air dan didukung dengan pemanfaatan lahan yang banyak untuk perkebunan juga ikut mendukung kawasan mata air jompi sebagai kawasan lindung resapan air.

\section{Kawasan sekitar mata air}

Adapun keadaan kawasan mata air, antara lain :

a) Kondisi alam di Kawasan Mata Air Jompi dengan suhu udara sejuk dan rindang, alam yang masi alami, serta sumber mata air yang melimpah menjadikan kawasan mata air jompi sering di kunjungi orang untuk rekreasi melihat sumber mata air atau melaksanakan kegiatan seperti berenang dan berendam. Sehingga Kawasan Mata Air Jompi berpotensi untuk di kembangkan sebagai obyek wisata alam.

b) Terdapat sumber mata air yang besar dikawasan ini. Sumber mata air ini tidak hanya satu tetapi mencapai beberapa tempat, terbukti banyak pengguna air mata air Jompi yang langsung mengambil mata air dari sumbernya seperti PDAM kota Raha.

c) Kemudahan dalam mengakses Kawasan Mata Air Jompi ini karena tempatnya cukup strategis berada di tengah-tengah Kota Raha dan jalanan menuju mata air tidak jauh dari jalan raya sekiat $100 \mathrm{~m}$ dan pengujung bisa jalan kaki untuk mengelilingi kawasan mata air yang saling berdekatan.

Tetapi sebagai kawasan yang di lindungi mata air jompi masi mengalami beberapa permasalahan di sekitar mata air, antara lain:

a) Kawasan mata air jompi yang seharusnya dilindungi bahkan dipelihara sampai saat ini kondisinya dibiarkan saja kotor. Belum ada pemeliharaan dari pemerintahan daerah setempat. Sedimentasi di mata air satu akibat meluapnya air sungai di desa labaha pada waktu musim hujan semakin banyak sehingga mengakibatkan dangkalnya mata air di area permandian mata air satu dan air menjadi keruh.

b) Kondisi lingkungan di kawasan mata air mengalami penurunan terlihat dari banyaknya sampah dikawasan ini, penurunan debit air, pemipaan dari para pengguna air yang tidak teratur sehingga memunculkan kesan kumuh dan kotor dari kawasan mata air.

c) Belum adanya kerja sama yang maksimal mengenai pemanfaatan sumber ait kawasan mata air jompi oleh pemerintah Kabupaten Muna selaku pemilik aset dengan para pengguna air. PMDA Muna baru melaksanakan kerja sama dengan PDAM kota raha.

d) Kondisi mata air yang di fungsikan untuk permandian dan berendam masih relatif baik tapi terkesan kurang terawat dan seadanya, fasilitas-fasilitas penunjang yang kurang lengkap, hanya tersedia warung-warung kecil, tempat berganti baju. Hal ini merupakan kendala bagi pengunjung yang menginginkan kenyamanan dalam tempat rekreasi.

Tetapi melihat hasil penelitian pemanfaatan sumber mata air sebelumnya, potensi terbesar Kawasan mata air jompi sebenarnya adalah sumber mata air itu sendiri sehingga kawasan ini dilindungi. Dari sumber mata air itu PDAM Kota Raha dapat memasok kebutuhan air bersihnya untuk mendukung pembangunan maupun pengembangan wilayahnya. Berdasarkan hasil penelitian pemanfaatan sumber mata air dan keadaan lingkungan mata air Jompi dapat ditarik kesimpulan bahwa Kawasan Jompi tepat untuk difungsikan sebagai kawasan lindung maupun dijadikan tempat 
wisata . Tetapi pemanfaatan yang utama adalah sebagai kawasan lindung terkait adanya sumber mata air besar di kawasan ini.

\section{B. Deskripsi Tentang Pemanfaatan Sumber Mata Air Jompi Kelurahan Laende Kecamatan Katobu Kabupaten Muna \\ 1. Sumber daya air}

Area mata air jompi merupakan rangkaian anak sungai yang berada di Desa Labaha. Debit air yang keluar dari seluruh area mata air Jompi ini mencapai ribuan liter/detik. Air di area mata air Jompi ini merupakan air tanah yang muncul ke permukaan sebagai mata air, karena kemunculannya menyebar di permukaan tanah, maka mata air Jompi secara hidrologi diklasifikasikan sebagai rembesan.

Mata air ini berasal dari beberapa daerah tangkapan hujan (catchmen area) pada area terdapat pohon-pohon dalam berbagai macam vegetasi besar. Jadi daerah tangkapan air mata air ini adalah perbukitan tersebut yang mengalir sebagai aliran tanah dan muncul kepermukaan tanah. Ditinjau dari sifat pengalirannya, mata air Jompi tergolong mata air menahun (perennial spring) yaitu mata air yang mengeluarkan air sepanjang tahun dan tidak begitu terpengaruh musim.

\section{Sebagai sumber air bersih}

Debit air yang cukup besar menjadikan mata air Jompi mempunyai peranan yang cukup panjang. Mata air Jompi dimanfaatkan sebagai sumber air baku oleh PDAM Kota Raha, adapun untuk daerah-daerah terpencil yang ada di Kabupaten Muna air di distribusikan melalui mobil-mobil pik-up yang di bayar sebesar 25 ribu.

Pemanfaatan air ini sudah berjalan sejak lama. Kerja sama dalam memanfaatan air dari kawasan mata air jompi sudah ada antara pemerintah Kabupaten Muna dengan PDAM Kota Raha. Dalam kerja sama ini pemerintah daerah memberikan penyertaan modal kepada PDAM dalam bentuk uang hingga menjadi sebesar Rp.51.497112.000, yang akan diberikan secara bertahap sesuai kemampuan keuangan daerah yang selanjutnya akan dimuat dalam APBD. Sesuai ketentuan dalam upaya penguatan struktur permodalan Perusahaan Daerah Air Minum (PDAM) Kabupaten Muna, Pemerintah Daerah dapat melakukan penyertaan modal guna meningkatkan kualitas, kuantitas, dan kapasitas pelayanan air minum kepada masyarakat.

Pemanfaatan mata air oleh PDAM Kabupaten Muna sebagai air bersih digunakan untuk melayani wilayah Kota Raha dan daerah-daerah yang ada di Kabupaten Muna, melalui tiga pipah besar yang di tampung telebih dahulu dalam bak besar oleh pihak Perusahaan Daerah Air Minum (PDAM) lalu distribusikan ke rumah warga dibeberapa Kelurahn yang ada di Kota Raha.

\section{Air untk kebutuhan lain (mencuci dan berenang}

Selain dimanfaatkan untuk kebutuhan air bersih, air dari mata air Jompi dimanfaatkan oleh masyarakat dan orang-orang yang berkunjung ke kawasan mata air jompi untuk mencuci, berenang dan aktivitas lainnya. Air yang digunakan untuk keperluan ini adalah air yang berada pada air terjun yang ada di kawasan ini.

\section{Wisata Air Tawar}

Dari hasil penelitian kawasan Mata Air Jompi juga dijadikan sebagai tempat wisata air tawar . Kawasan ini banyak dikunjungi orang untuk melihat pemandangan alam dan sumber air maupun berendam. Hal tersebut merupakan potensi yang dapat dikembangkan dan menjadikan Kawasan Mata Air Jompi sebagai obyek wisata. Dengan harapan Kawasan Mata Air Jompi dapat menjadi titik pertumbuhan bagi pengembangan wilayah di Kecamatan Katobu dan daerah sekitarnya. 


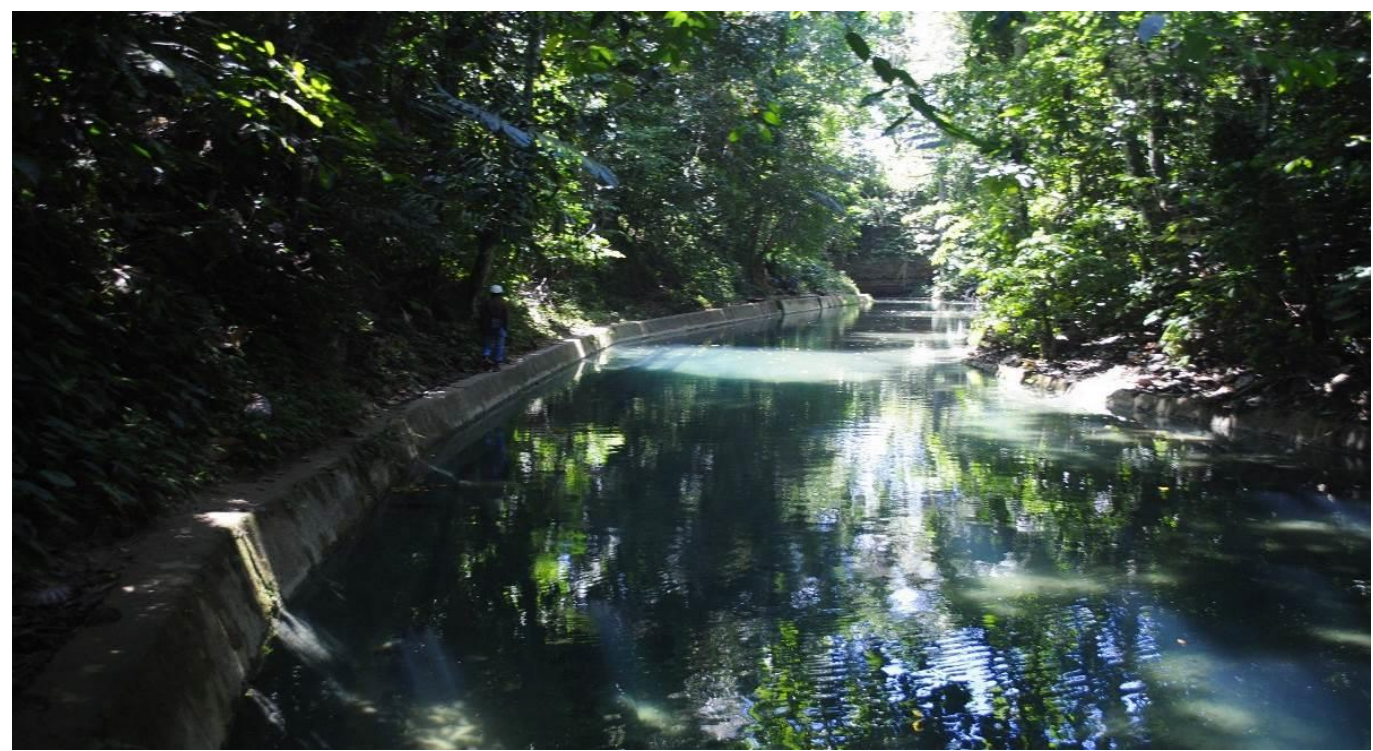

Gambar 2. Area wisata (hasil observasi 2019)

Melihat potensi wisata yang ada di Kawasan Mata Air Jompi adalah berbasis pada wisata air, maka apapun bentuk kegiatan pengembangan pariwisata disini harus menjaga keberlanjutan sumber mata air Jompi karena mempunyai kualitas dan kuantitas sumber mata air Jompi berarti menurun pula fungsi lindung maupun pengembangan pariwisata yang ada.

Partisipasi masyarakat juga harus dilibatkan, baik dalam perencanaan, pelaksanaan maupun pengelolaan Kawasan Mata Air Jompi sehingga masyarakat mempunyai rasa memiliki yang berimbas pada rasa memelihara sehingga pengembangan pariwisata di Kawasan Mata Air Jompi menjadi tetap berkelanjutan. Partisipasi dapat berupa pelibatan masyarakat secara langsung yang di mulai dari aktifitas sosialisasi sampai dengan pembinaan masyarakat terkait dengan kegiatan yang berhubungan dengan pariwisata.

Oleh sebab itu terhadap rencana pemerintah yang akan memanfaatkan dan mengembangkan kawasan ini menjadi obyek wisata demi pengembangan wilayah haruslah pengembangan pariwisata yang tetap menjaga kelestarian lingkungan dan mengedepankan fungsi Kawasan Mata Air Jompi sebagai kawasan lindung, mengingat dampak negatif yang dapat ditimbulkan dari aktifitas pengembangan pariwisata seperti berkurangnnya daerah resapan air, pencemaran sumber mata air oleh limbah, penurunan debit air dan sebagainya. Dalam hal ini diperlukan campur tangan dan kepedulian serta komitmen kuat dari pemerintah dan stake holder yang terlibat serta adanya partisipasi masyarakat dalam mengembangkan kawasan ini, sehingga Kawasan Mata Air Jompi menjadi bersih dan terkelolah, memberi kontribusi yang positif bagi masyarakat, pemerintah, pengguna air maupun pengembangan wilayah sekitarnya.

\section{Pembahasan}

Mata air Jompi merupakan sumber utama yang dimanfaatkan oleh masyarakat kota Raha untuk memenuhi kebutuhan air bersih sehari-hari khususnya pada saat musim kemarau tiba karena kondisinya yang terus mengalir sepanjang tahun dan tidak pernah mengalami kekeringan. Karena Das Jompi berada di tengah-tengah hutan lindung Warangga yang memiliki banyak pohon-pohon besar dan semak belukar yang mampu menahan air dalam jumlah besar apabila terjadi hujan. Dimana Sumber mata air yang ada dipermukaan dan bawah permukaan tanah berasal dari hujan. Hujan yang turun ke bumi sebagian akan mengalir sebagai air permukaan dan sebagian lagi meresap kedalam tanah mengalir dari daerah yang lebih tinggi yaitu dari daerah resapan atau daerah imbuhan menujuh daerah yang lebih rendah dan akhirnya menuju ke laut (Danaryanto dkk, (2015). 
Kawasan mata air Jompi yang dimanfaatkan sebagai kawasan lindung resapan air, kondisi fisik lingkunganya sudah mengalami penurunan terlihat dengan banyaknya sampah di sekitar area permandian hingga menurunya debit air berdasarkan data dari DPU Pengairan Kabupaten Muna, dimana debit dari mata air Jompi pada tahun 2010 sebesar \pm 25 liter/detik. Dalam hal ini berarti telah mengalami penurunan debit sebesar sepuluh kali sejak dekade terakhir yang sebelumnya sebasar \pm 50 liter/detik. Indikator yang dapat dirasakan adalah terjadinya fluktuasi air sungai.

Dalam pemanfaatanya sumber mata air jompi sebagian besar dimanfaatkan untuk memenuhi kebutuhan air bersih masyarakat kota raha yang ditampung oleh PDAM lalu disalurkan kerumah warga bukan hanya itu mata air jompi jg dimanfaatkan sebagai tempat wisata air tawar. Adapun untuk daerah terpencil yang ada di Kabupaten Muna air di distribusikan melalui mobil-mobil pik-up yang di isi ulang pada pipa PDAM.

Sebagai kawasan lindung sumber mata air Jompi sudah memiliki perakat hukum dalam menjaga kelestariannya. Dan masyarakat sekitar harus dilibatkan agar tetap senantiasa menjaga kelestarian hutan maupun sumber mata air jompi agar senantiasa sumber mata air bisa terus dimanfaatkan dan memenuhi kebutuhan air bersih masyarakat Kabupaten Muna.

Upaya yang dilakukan pemerintah daerah untuk saat ini baru melakukan survei di area mata air dan hutan, tetapi pemerintah Kabupaten Muna masih menunggu anggaran dari pemerintah pusat untuk melakukan penataan kembali Kawasan Mata Air Jompi.

Oleh karena itu, hutan harus di kelolah, dikembangkan dan dimanfaatkan secara baik, kawasan hutan lindung Jompi adalah salah satu kawasan hutan lindung di Kabupaten Muna yang memiliki sumber mata air yang saat ini banyak memanfaatkan sebagai kebutuhan air minum dan air bersih sehari-hari (Dasmin Sidu, 2010).

\section{SIMPULAN DAN SARAN}

\section{KESIMPULAN}

Kesimpulan dalam penelitian ini yaitu:

1. Kawasan mata air Jompi dilihat dari kondisi fisik sumber mata air Jompi sudah mengalami penurunan pada lingkungannya terlihat dengan banyaknya sampah dan penurunan debit air . Berdasarkan data dari DPU Pengairan Kabupaten Muna, debit dari mata air Jompi pada tahun 2010 , bahwa dari hari kehari debit air jompi menurun menjadi \pm 25 liter/detik, sebelumnya \pm 50 liter/detik.

2. Sumber mata air Jompi sebagian besar di manfaatkan untuk memenuhi kebutuhan air bersih masyarakat Kota Raha yang di tampung oleh PDAM lalu di salurkan ke rumah rumah warga bukan hanya itu sumber mata air juga dimanfaatkan untuk berendan dan rekreasi. Adapaun untuk daerah daerah terpencil yang ada di kota raha air di distribusikan melalui mobil-mobil pik-up yang di bayar sebesar 25 ribu.

\section{SARAN}

Adapun saran yang ingin diajukan penulis adalah terkhusus bagi:

1. Pemerintah Daerah setempat agar meningkatkan pengawasan terhadap aktivitas penebangan liar yang di lakukan di Kawasan Hutan Lindung Jompi terhadap oknum-oknum yang tidak bertanggung jawab yang merusak kelestarian hutan.

2. Bagi masyarkat agar ikut menjaga kelestarian Hutan Lindung Jompi agar sumber mata air Jompi tetap terjaga hingga anak cucu kita kedapan bisa ikut merasakan sumber mata air yang sejak dulu berada di Kota Raha. Adapun bagi peneliti selanjutnya, agar menggunakan pendekatan kekeluargaan kepada masyarakat supaya masyarakat terbuka dan dalam memberikan informasi terkait dengan keperluan penelitian. 


\section{DAFTAR RUJUKAN}

BPS. (2015). Kabupaten Muna dalam Angka proyeksi. Sulawesi Tenggara: Badan Pusat Statistik Sulawesi Tenggara.

Danaryanto dkk, (2015). Model Penentuan Kawasan Resapan Air untuk Perencanaan Tata Ruang Berwawasan Lingkungan.Jakarta: Badan Pengkajian dan Penerapan Teknologi.

Dasmin Sidu, (2010). Kawasan Hutan Lindung. Yogyakarta: Universitas Gadjah Mada.

Fandeli, Chafid dan Mukhlison. (2011). Perencanaan Kepariwisataan Alam. Fakultas Kehutan UGM. Yogyakarta. Volume 31, Nomor 2,339-350.

Hendrayana, H., (2013), Hidrogeologi Mata Air. Universitas Gadjah Mada. Yogyakarta. Volume 15, Nomor 2,81-87.

Karyono. A Hari. (2010) Kepariwisataan, Jakarta: PT Gramedia Widiasarana Indonesia. Volume 1 , Nomor 48-59.

Kodoatie, R. J dan R. Sjarief. (2010). Tata Ruang Air. Penerbit Andi. Yogyakarta. Volume 11, Nomor 58-59.

Sartohadi,Junun dkk. (2012). Pengantar Geografi Tanah. Yogyakarta: Pustaka Pelajar. Volume 9, Nomor 86-97.

Tunggul, E. (2012). Pengelolaan Sumber Air di Desa Jawesari Kecamatan Limbangan Kabupaten Kendal. Jurnal Kesehatan Masyarkat. Volume 4, Nomor 52012.

Waryono. Tarsoen. (2010). Peranan Kawasan Resapan dalam Pengelolaan Sumberdaya Air. Depok : Jurusan Geografi FMIPA Universitas Indonesia. Volume 5,

\section{Editor In Chief}

emankgiman@unm.ac.id

\section{Publisher}

\section{Geography Education, Geography Departemenr, Universitas Negeri Makassar}

Ruang Publikasi Lt.1 Jurusan Geografi Kampus UNM Parangtambung, Jalan Daeng Tata, Makassar.

Email : lageografia@unm.ac.id

Info Berlangganan Jurnal 085298749260 / Alief Saputro 